\title{
IS THE RIGHT TO DIE WITH \\ DIGNITY CONSTITUTIONALLY \\ GUARANTEED? BAXTER $V$ \\ MONTANA* AND OTHER \\ DEVELOPMENTS IN PATIENT \\ AUTONOMY AND PHYSICIAN \\ ASSISTED SUICIDE
}

\author{
Suhayfa Bhamjee \\ LLB LLM \\ Senior Lecturer, School of Law \\ University of KwaZulu-Natal, Pietermaritzburg
}

\begin{abstract}
"The right to life, thus understood, incorporates the right to dignity. So the rights to human dignity and life are entwined. The right to life is more than existence - it is the right to be treated as a human being with dignity: without dignity, human life is substantially diminished." (O'Regan $\mathrm{J}, S \vee$ Makwanyane 19953 SA 391 (CC).)
\end{abstract}

\section{SUMMARY}

This article examines the question of whether the right to life encompasses the right to die with dignity. It looks at the concepts of autonomy and paternalism as they exist as major themes on either side of the debate. Physician Assisted Suicide (Voluntary Euthanasia) has come under the spotlight in several jurisdictions, not just our own. Most recently in Montana, USA, the issue came before the Supreme Court for deliberation. The states of Washington and Oregon have legislations specific to PAS, legitimizing assisted suicide and removing wrongfulness from the actions of a physician who assists in the prescribed manner. Montana does not have specific legislation, but instead relied on the clauses of its Constitution, and it was held that the right to die with dignity is constitutionally guaranteed in that state.

Here, argument is made suggesting that the right to die with dignity, in other words, to seek and easy passing through PAS, is also guaranteed in our Constitution.

The case was brought before the Supreme Court of Montana. Argument was heard on 2 September 2009. The Supreme Court supported a patient's right to die with dignity. Also, in a poll, $63 \%$ (a $2 / 3$ rds majority) of voters supported the court's decision. 


\section{$1 \quad$ INTRODUCTION}

The ability to exercise choice on the termination of one's own life is limited. The limitations exist as a result of religious, moral, ethical and legal convictions of the community at large. ${ }^{1}$ However, as with everything in life, there appears to be a shift in perceptions of the right to life and the right to die.

In 1997, the Oregon Death with Dignity Act was passed allowing doctors to prescribe lethal medication which would assist patients who met certain criteria to end their lives. Some of the criteria are:

- Patients must be in the final 6 months of a terminal illness;

- patients must make two oral requests and have done a written request to die, separated by a two-week period;

- two doctors must confirm the diagnosis;

- the doctor can prescribe a lethal prescription of drugs to the patient; and

- the drugs must be administered by the patients themselves.

In 2004325 people met the criteria and obtained lethal prescriptions and 208 used them.

In apparent conflict with the legislation was the Controlled Substances Act of 1970 which prohibits doctors from prescribing regulated drugs for use in physician-assisted suicides.

The United States Supreme Court had to deal with these conflicting pieces of legislation in the case of Gonzales, Attorney General, et al v Oregon et $\mathrm{a} \boldsymbol{l}^{\beta}$ and pronounced judgment on 17 January 2006. More recently, the judiciary in Baxter v Montana ${ }^{4}$ in 2008 considered the issue in light of the State's constitutionally guaranteed rights to equal protection, individual dignity and privacy. This decision was then taken to the Supreme Court in 2009, where the decision was confirmed.

This article looks at a terminally ill, yet competent patient and whether or not he ${ }^{5}$ has the right to obtain a prescription for drugs which would hasten his death if he so chose to administer them. Essentially, what is looked at is the question of whether the right to life encompasses the right to die with dignity.

Scherer and Simon Euthanasia and the Right to Die: A Comparative View (1999).

http://query. nytimes.com/gst/fullpage.html?res=9C01E6DB153FF93BA25752C0A9609C8

(accessed on 2006-05-15).

546 U.S (2006) No 04-623.

Cause No ADV -2007-787.

The masculine is used for ease of reference, but this by no means excludes the feminine. 


\section{OREGON AND WASHINGTON}

In a leap which can only be described as quantum, the state of Oregon passed The Oregon Death with Dignity Act on the 27 October 1997. The Act is further evidence of the shifting of moral values and tolerance for end of life decisions.

Contrary to fears that legislation of the kind would "open the flood gates" and lead to abuse, the Act calms those troubled waters by permitting PAS within very narrowly prescribed circumstances. The Act describes a "qualified patient" as "a capable adult who is a resident of Oregon and has satisfied the requirements of ORS 127.800 to 127.897 in order to obtain a prescription for medication to end his or her life in a humane and dignified manner". Thus, there must be a written request made by a patient who is a major and terminally ill. Statistics show, that since its promulgation in 1997, only 400 people have used PAS. ${ }^{6}$

Furthermore, the attending physician is also tasked with responsibilities as far as diagnosing the terminal illness, and then determining whether the patient qualifies for lethal drugs. The Act also caters for a sanction for abuse by the physician, for example loss of practitioner's licence.

The legislation is significant not only because it creates a window through which physicians will escape liability for "killing" their patients, but also because it affords the terminally ill a manner of dying with dignity, in a humane, and painless manner.

The validity of the Act was tested in the Supreme Court of the United States in $2005,{ }^{7}$ rejecting a Bush administration attempt to punish doctors who help terminally ill patients die:

"Justices, on a 6-3 vote, said the 1997 Oregon law used to end the lives of more than 200 seriously ill people, trumped federal authority to regulate doctors. New Chief Justice John Roberts backed the Bush administration, dissenting with the majority for the first time. ${ }^{8}$

There is only one answer: The president is not telling the truth. $\mathrm{He}$ is only willing to respect the decisions of Americans if he agrees with them. He is only willing to advocate for a conservative court if it upholds a social agenda that he agrees with. He is not willing to allow a state to follow a policy regarding the terminally ill if he does not agree with it. And he clearly expects the Supreme Court to 'legislate from the bench' when it suits his moral agenda.

The federal government should not have brought the case against Oregon's law. And the Supreme Court should not listen to the cockamamie argument that a statute intended to prevent the illicit use of drugs somehow gives the federal government the right to tell the citizens of Oregon how they must die when they are terminally ill."

6 Statistics at Eight Annual Report on Oregon's Death with Dignity Act, Department of Human Services 19-24; and http://health.blogs.foxnews.com/2009/05/28/assisted-suicide-legal-inwashington/ (accessed on 2009-06-14).

Gonzales, Attorney General, et al $v$ Oregon et al supra.

http://www.msnbc.msn.com/id/10891536/.

http://www.msnbc.msn.com/id/9611497/. 
The Gonzales ${ }^{10}$ case, although argued and debated mainly as a question of administrative law, ${ }^{11}$ still sends the resounding message that physicians who assisted their patients to end their lives would not be criminally liable, provided that the criteria for qualification for PAS were met, these being:

- Patients must be in the final six months of terminal illness;

- patients must make two oral and one written request to die, separated by a two-week period;

- patients must be mentally competent to make the decision;

- two doctors must confirm the diagnosis;

- lethal prescription of drugs are to be prescribed by the doctor but administered by the patients themselves; and

- the option of PAS is only available to people who are resident of the state of Oregon (The Act prescribes how that is to be determined, that is, possession of a valid Oregon state drivers licence, etcetera).

Washington followed suit and in 2009 with the Washington Death with Dignity $\mathrm{Act}^{12}$ which took effect on 5 March 2009. In May 2009, the first patient to make use of the legislation was Linda Fleming. ${ }^{13}$ The right to physician-assisted suicide was further confirmed by a court in Montana ${ }^{14}$ in December 2008. The court based its decision on Montana's Constitution, and not on specific legislation as in Washington or Oregon. ${ }^{15}$

The interests of the community appear to be served and disserved on both ends of the spectrum. We accept at large that communal interests and morality must be safeguarded, but at the same time, the nature of man and community is to embrace autonomy and be allowed to make decisions freely that affect one's own life.

Strides have been made regarding legal capacity. States recognize that a human being who is a major and who is sane, has the capacity to make decisions regarding all facets of his life, whether they be business-related or personal. That, however, isn't as simply implemented as it is stated, and is subject to the qualification that there are certain aspects which the State,

10 Supra.

11 Whether former Attorney General John Ashcroft's 2001 interpretation of the federal Controlled Substances Act (CSA) to outlaw the use of drugs for assisted suicide is valid or whether the Justice Department overstepped its regulatory powers.

$1270.245 \mathrm{RCW}$.

13 "Cancer Patient Commits Physician-assisted Suicide under Washington Law" http://jurist.law.pitt.edu/paperchase/2009/05/cancer-patient-commits-physician.php (accessed on 2009-05-27).

14 Baxter v Montana supra.

15 "On December 5 2008, Montana State District Court Judge Dorothy McCarter issued summary judgment to plaintiffs, holding that the state constitution's individual dignity clause and the constitution's 'stringent' right of privacy are 'intertwined insofar as they apply to plaintiffs' assertion that competent terminal patients have the constitutional right to determine the timing of their death and to obtain physician assistance in doing so." http://www.medicalnewstoday.com/articles/132104.php (accessed on 2009-06-14). 
despite the aforementioned criteria being fulfilled, will not allow an adult to make decisions about. ${ }^{16}$ In fact, it goes further by criminalizing such decisions.

We see the battle between paternalism and autonomy in many facets of criminal law, but here the writer will be discussing the dichotomy only in the context of end of life decisions. This debate has been fuelled by language coloured in morality and religion on the one hand, and arguments around an individual's right to choose and take cognisance of his own actions, choices, and repercussions of those actions and choices, on the other.

Despite such conflict, the statistics in Oregon speak for themselves:

rescriptions Written for Lethal Medication

(Oregon 'Death with Dignity Act')

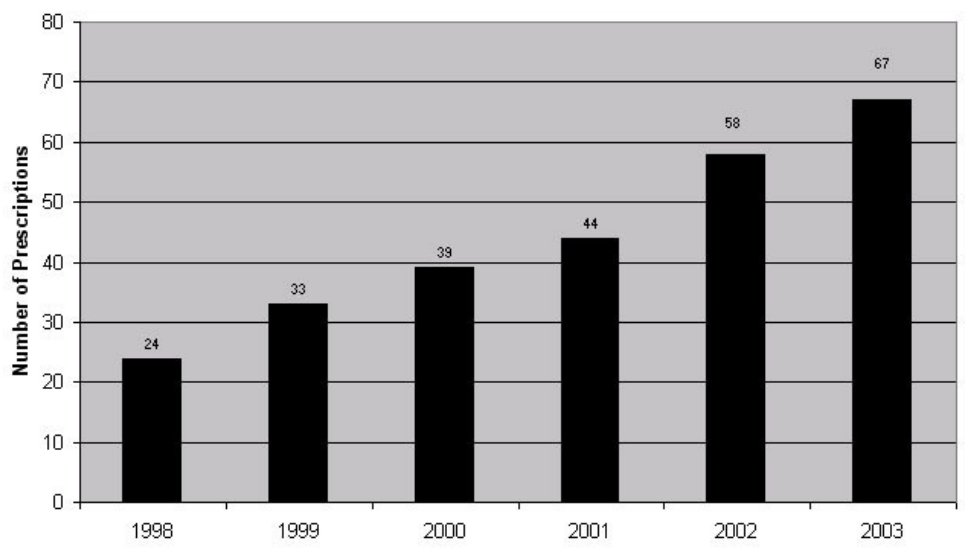

Figure 1. Number of DWDA Prescription Recipients and Deaths, by Year, Oregon, 1998-2005

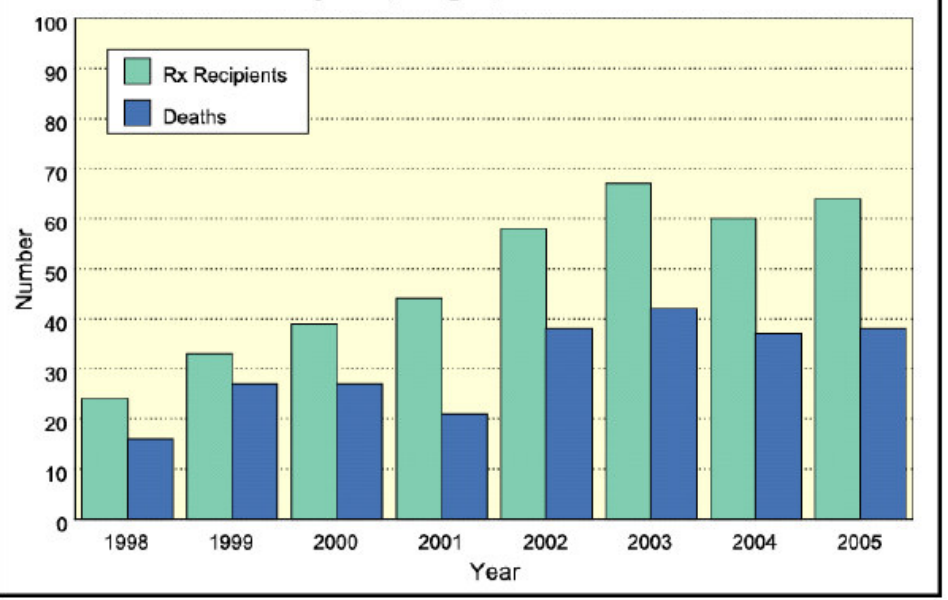

16 The paternalism argument - the state as "big-brother", etc. 
This article deals with only one of those aspects, namely the capacity of an adult to make the choice to live or die, and secondly, the legal consequences which flow from having made such choice. Essentially, what is needed is legislative and judicial intervention (either specific legislation is created to legitimize Physician Assisted Suicide - as in Oregon; or the provisions in the Constitution, Act 108 of 1996 is used - as in Baxter v Montana ${ }^{18}$ ).

\section{BAXTER $v$ MONTANA ${ }^{19}$}

\section{Facts}

The plaintiff was a 75-year-old man suffering from leukaemia with diffuse lymphadeopaty (a terminal form of cancer). He had been through several sessions of chemotherapy, each session of dosages becoming less effective. The combination of the cancer, his heart problems and the chemotherapy, resulted in his being afflicted with several other disorders inter alia "anemia, chronic fatigue and weakness, nausea, night sweats, intermittent and persistent infections, massively swollen glands, easy bruising, significant ongoing digestive problems, and generalized pain and discomfort" (judgment 3). The nature of his cancer is that there is no cure, neither is there any prospect of recovery. As a result, plaintiff (Baxter) seeks assisted suicide when his suffering becomes unbearable.

The "plaintiffs assert(ed) that competent terminally ill patients must be permitted to use the assistance of a physician to obtain drugs that the patients can self-administer if and when those patients decided to terminate their lives". ${ }^{20}$

The State contended that this would not be legal and would still fall under the category of murder for anyone who offers such assistance.

The court ultimately had to decide whether a "Competent Terminal Individual has a Constitutional right to choose the time and manner of his death without government intrusion". ${ }^{21}$

\footnotetext{
Eighth Annual Report on Oregon's Death with Dignity Act, Department of Human Services Office of Disease Prevention and Epidemiology, March 9, 2006 "Both the number of prescriptions written and the number of Oregonians using PAS vary annually but have been relatively stable since 2002. In 2005, 39 physicians wrote 64 prescriptions for lethal doses of medication. In 1998, 24 prescriptions were written, followed by 33 in 1999, 39 in 2000, 44 in 2001, 58 in 2002, 68 in 2003, and 60 in 2004." - Reasons why people killed themselves in Oregon in 2003: $84 \%$ feared loss of autonomy; $84 \%$ concerned about decreasing ability to partake in enjoyable activities; $47 \%$ concerned with loss of bodily functions; $37 \%$ concerned about burdening family, friends or caregivers; $26 \%$ feared inadequate pain relief.

18 Supra.

19 Supra.

20 Supra 4

21 Supra 6
} 


\section{Argument}

Plaintiffs' arguments were based largely on the Montana Code Annotated ${ }^{22}$ ("MCA") and the Montana Constitution of 1972 (which guarantees certain fundamental rights).

The MCA makes it an offence to "purposely or knowingly cause the death of another human being", ${ }^{23}$ that doing so while "under the influence of extreme mental or emotional stress for which there is reasonable explanation or excuse"; ${ }^{24}$ and that it is also an offence to do so negligently. ${ }^{25}$

It is clear that where conduct is deemed the cause of the death of the victim (the "but for" test), an offence has occurred. ${ }^{26}$

It was submitted, however, that consent of the "victim" is a defence to a criminal charge. ${ }^{27}$ However, such consent is ineffective if:

"(a) it is given by a person who is legally incompetent to authorize the conduct charged to constitute the offense;

(b) it is given by a person who by reason of youth, mental disease or defect, or intoxication is unable to make a reasonable judgment as to the nature or harmfulness of the conduct charged to constitute the offense;

(c) it is induced by force, duress, or deception; or

(d) it is against public policy to permit the conduct or the resulting harm, even though consented to."

Taking the above into consideration, the plaintiffs then argued that in terms of the Montana Constitution, public policy should in fact allow physicians to provide aid in dying to their mentally competent, terminally ill adult patients who are experiencing severe suffering at the end of life and request such assistance. The effect being that the physician would be absolved of criminal liability for what otherwise would be purposefully "causing" the death of another.

In terms of the Montana Constitution ${ }^{28}$ it was argued that the homicide statutes deny terminally ill patients the right to the integrity of and personal autonomy over their own bodies; the right to decide for themselves the most fundamental questions about the meaning and value of their lives and the intrinsic value of life in general; the right to liberty, of which they may not be

22 2009: - the particular focus was on Title 45, the criminal code - http://data.opi.mt.gov /bills/mca toc/index.htm.

23 MCA 45-5-102 - Deliberate homicide, for which the punishment is death.

24 MCA 45-5-103 - Mitigated Deliberate Homicide, the punishment for which is 2 to 40 years' imprisonment or a fine of $\$ 50000$.

25 MCA 45-5-104 - Negligent Homicide, the punishment for which is up to 20 years' imprisonments and/or a fine not exceeding $\$ 50000$.

26 MCA 45-2-201 - Causal relationship between conduct and result - effectively making a physician who intentionally provides aid in dying assistance to a terminally ill patient, prosecutable and subject to the same penal sanctions outlined above.

27 MCA45-2-211.

28 Article II, ss 10; 4; 17; 3. 
deprived without due process of law; and the inalienable right to seek safety, health and happiness in lawful ways.

Ultimately the arguments were made to have the crimes of deliberate homicide $^{29}$, mitigated deliberate homicide ${ }^{30}$ and negligent homicide ${ }^{31}$ declared unconstitutional in regard to physician assisted suicide (where a physician assists a mentally competent, terminally ill adult patient anticipating a dying process intolerable).

The State also relied on the provisions of the Montana Constitution in making its argument against the legitimization and legalization of PAS. The state raised the limitation of fundamental rights as far as they related to compelling state interests, namely: the preservation of human life, the need to protect vulnerable groups from Potential Abuses, the need to protect the integrity and ethics of the medical profession.

It argued further that ${ }^{32}$

"declaring constitutional rights for a competent terminally ill patient is premature because there is not definition of 'competent' or 'terminally ill'. Competency is easily determined by the patient's doctor. Treating physicians are frequently called upon to determine competency of their patients for purposes of guardianship and other legal proceedings. Whether a patient is terminally ill can also be determined by the physician as an integral component of the physician-patient relationship. These issues are insufficient to impinge on the patient's right to die with dignity."

In its concluding remarks, the State impressed upon the court that this was a matter best left to the legislature, and should not be determined by the court.

\section{Judgment}

The court held that people have, in terms of the Montana Constitution, a constitutionally guaranteed right to die with dignity: "a competent terminally ill patient has the constitutional right to die with dignity. This right is protected by Article II, sections 4 and 10, of the Montana Constitution and necessarily incorporates the assistance of his doctor, as part of a doctor-patient relationship, so that the patient can obtain a prescription for drugs that he can take to end his own life, if and when he so determines".

In reaching this conclusion, McCarte $\mathrm{J}$ quotes from the Armstrong $v$ State ${ }^{33}$ decision with consensus that "Article II, section 10 of the Montana Constitution broadly guaranteed each individual the right to make medical judgments affecting her or his bodily integrity and health in partnership with a chosen health-care provider free from government interference." Clearly the

\footnotetext{
MCA 45-5-12.

MCA 45-5-103.

MCA 45-5-105.

Supra 22.

1999 MT 26118.
} 
preamble of the constitution and its purport to value individual autonomy above all else is echoed in the above quotation. She drives the point further (19) by stating emphatically that

"The same rationale applies to the present case. Given a competent terminal patient's right to determine the time to end his life, in consultation with his physician, the method of effecting the patient's death with dignity would require the assistance of his medical professional. The physician-patient relationship would enable the terminal patient to consult with his doctor as to the progress of the disease and the expected suffering and discomfort, and would enable the doctor to prescribe the most appropriate drug for life termination, leaving the ultimate decision and timing up to the patient. But for such a relationship, the patient would increasingly become physically unable to terminate his life, thus defeating his constitutional right to die with dignity. If the patient were to have no assistance from his doctor, he may be forced to kill himself sooner rather than later because of anticipated increased disability with the progress of his disease, and the manner of the patient's death would more likely occur in a manner that violates his dignity and peace of mind, such as by gunshot or by an otherwise unpleasant method causing undue suffering to the patient and his family."

\section{GLOBAL COMPARISONS}

In most jurisdictions, PAS is still illegal and recognized as murder. However, some (progressive) states have legalized the procedure, thus removing any penalty for "murder". Belgium, The Netherlands, Colombia, the States of Oregon and Washington in the USA as well as the Northern Territory of Austraila (for a brief period) all legalized PAS. ${ }^{34}$

\section{South Africa - Grotjohn ${ }^{35}$ v Hartmann $^{36}$}

Physician-assisted suicide (PAS) is the voluntary termination of one's own life by administration of a lethal substance with the direct or indirect assistance of a physician. According to the Oregon Act it is the practice of providing a competent patient with a prescription for medication for the patient to use with the primary intention of ending his or her own life.

In South Africa, the term "voluntary active euthanasia" has been used, but it expresses the same sentiment as in Physician-Assisted-Suicide. ${ }^{37}$

"Voluntary active euthanasia (VAE) refers to a clearly competent patient making a voluntary and persistent request for aid in dying. In this case the individual or a person acting on that individual's behalf (physician or lay person, according to the law of the country) takes active steps to hasten death. That active step can be either the provision of the means (i.e. a lethal drug) for self-administration (orally or parenterally), or the administration by a

34 Egan "Should the State Support the 'Right to Die'?" December 2008 1(2) SA Journal of Bioethics and Law 47 47-48.

35 Ex Parte Die Minister van Justisie: In re S v Grotjohn 19702 SA 355 (A).

36 S v Hartman 19753 SA 532 (C).

37 Ogunbanjo and Knapp van Bogaert "Voluntary Active Euthanasia: Is There Place for it in Modern Medicine?" 2008 50(3) SA Fam Pract 39 http://www.safpj.co.za/index.php/safpj/ article/ viewFile/1147/1132. 
tier. The provision of the means to die is called assisted suicide, assistance in dying, or PAS. The patient acts last.",

The definitions differ only in degree as pointed out in that:

"PAS involves an affirmative act, such as writing a prescription or providing the lethal drug. VAE requires the acts of providing and administering the lethal drug. In PAS the individual who wishes to die commits the final act, while in VAE, because that individual is unable to pose the last act, a proxy acts on his or her behalf. The difference is about the person who acts last. The intention and motivation are the same. Therefore, one might wonder whether the distinction is not a kind of hypocritical hair splitting.

When looking at criminal liability and the issue of causation, Kamisar ${ }^{40}$ asks the reader to consider the hypothetical scenario of a woman who swallows a lethal dose of medication which the physician has:

1. placed under her pillow;

2. placed in her hand; or

3. put in her mouth.

Although the arguments would be that 1 and 2 above are "assisted" as the patient makes the final decision to physically take the medication, option 3 would then appear to be active in that the physician administers the drug by placing it into the mouth of the patient. However, it could be further argued that the patient makes the final decision to swallow. If that argument succeeds, then the question of "what was the last act" as far as causation is concerned becomes futile.

What is relevant though, is that in either scenario, the physician will be, and is, in terms of South African law (as well as in other jurisdictions ), still liable for murder. This is because the common-law definition of murder does not cater for the defence of "physician-assisted suicide".

From the case law, legislation, and proposed legislation, we see that the issues which come to the fore are murder and euthanasia - that the community will not excuse murder, but has some measure of tolerance for euthanasia. Both cases, however, need to deal with the issue of consent to be killed. Two South African cases which help to take the arguments further are Grotjohn ${ }^{41}$ and Hartman. ${ }^{42}$

In Grotjohn ${ }^{43}$ the accused's wife wanted to commit suicide. He "assisted" her in that purpose in that he gave her a loaded gun, which she used, and successfully brought her life to an end. The court considered the issue of causation, and found that the accused was both the legal and factual cause

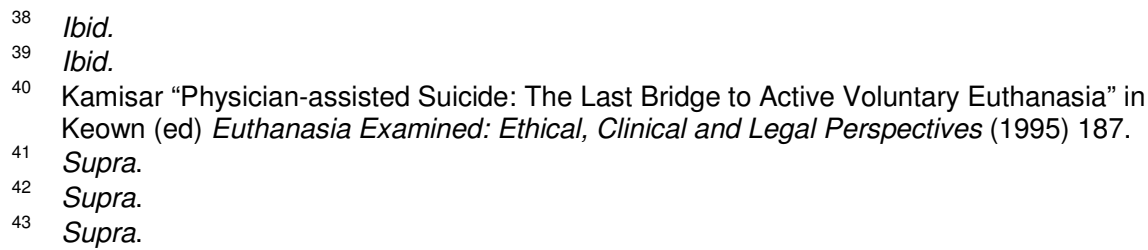


of his wife's death. The court dodged the bullet when Steyn CJ said he'd "prefer not to approve a general doctrine that the last 'voluntary and independent' act of the person committing suicide must always bring about the acquittal of the appellant, without some reservation in regard to the independence of the act. There is no doubt that the act of another which is the immediate cause of the result necessarily interrupts or excludes the causality of the perpetrator's act. To have this effect it would have to be a completely independent act, in the sense that it should be one which is totally unconnected and has no relationship to the act of the perpetrator; and this would not be the case where this act or behaviour is indeed the primary cause of the act, although the act in itself is innocent." ${ }^{44}$

However, Henning $\mathrm{J}$ in $S \vee$ Gordon $^{45}$ found the accused was not guilty of the murder. He stated as follows:

"To my mind, the mere fact that he provided the tablets knowing that the deceased would take them and would probably die cannot be said to constitute, in law, the killing of the deceased. The cause of her death was her own voluntary and independent act in swallowing the tablets. He undoubtedly aided and abetted her to commit suicide, but that is not an offence. The fact that he intended her to die is indisputable, but his own acts calculated to bring that result about fall short of a killing or an attempted killing by him of the deceased. One might say that the accused, as it were, provided the deceased with a loaded pistol to enable her to shoot herself. She took the pistol, aimed it at herself and pulled the trigger. It is not a case of qui facit per alium facit per se."

44 "Of 'n persoon wat 'n ander aanmoedig, help of in staat stel om selfmoord te pleeg, 'n misdaad begaan, sal afhang van die feite van die besondere geval. Met die oog op die gewysdes wat aanleiding tot die vrae gegee het, is dit egter nodig om op die voorgrond te stel dat die blote feit dat die laaste handeling die selfmoordenaar se eie, vrywillige, niemisdadige handeling is, nie sonder meer meebring dat bedoelde persoon aan geen misdaad skuldig kan wees nie. Die antwoord op die tweede vraag hang eweseer van die feitelike omstandighede af. Na gelang daarvan kan die misdaad moord, poging tot moord of strafbare manslag wees" 365H (translated); and R v Nbakwa 19562 SA 557 (SR), Beadle J stated as follows:

"The accused did not actually kill the deceased himself, but if his acts could be construed as an attempt to do so he could be legally convicted of attempted murder, since on an indictment for murder a verdict of attempted murder is a competent one. I will first consider, therefore, whether these particulars disclose on the part of the accused an attempt to murder the deceased. In my view the acts of the accused on this occasion do not go far enough to constitute an attempt; they go no further than what are commonly called acts of preparation. The accused provided a means for causing death and he persuaded the woman to kill herself, but the actual act which caused the death of the woman was the act of the woman herself. There was, to use a common legal expression, a novus actus interveniens between the actions of the accused and the death of the deceased which in my view broke the chain of causation between the act of the accused and the death of the deceased .... The direct cause of death was not the action of the accused. I come to the conclusion, therefore, that the accused's acts did not go far enough to constitute an attempt to murder; at most his acts went no further than acts of preparation.".

$45 \quad 19624$ SA $727(\mathrm{~N})$

46 731B-D. 
These words of Henning $\mathrm{J}$ can only be described as "Nostradamus-like", considering the facts of Grotjohn ${ }^{47}$ would unfold a few years later. The accused in Grotjohn ${ }^{48}$ was convicted of murder and given a four-year sentence, suspended for five years.

This then brings us to the next set of cases which deal with the concept of voluntary active euthanasia. This is the situation where the victim is suffering from a terminal illness, and requests that her life be brought to an end because the pain which she endures is unbearable, and in response thereto, the physician "assists" by administering a lethal injection.

The present position in South Africa is that PAS is unlawful, and the physician who provides such assistance would be convicted of murder (the sentences delivered are usually light and not enforced - which expresses community's tolerance and acceptance of euthanasia).

An interesting case is that of $R v$ Davidow, ${ }^{49}$ where the accused shot his mother in her hospital bed after she asked that her suffering be brought to an end. The accused's mental state was considered, and he was found not guilty; however, the act of killing his mother was none the less described as unlawful.

The facts in Hartmann ${ }^{50}$ differ in that on this occasion, the accused (a doctor) had himself administered the fatal injection, and it had not been at the request of the victim. The accused was convicted of having murdered his father who was suffering from terminal cancer. He was found guilty as he harboured the intention to kill his father, and although it may have been altruistic, the act of "mercy-killing" was still murder. However, the turning point was the sentence which the court pronounced. Van Winsen $\mathrm{J}$ states "This is a case, if ever there was one, in which, without having to be unfair to society, full measure can be given to the element of mercy. This is a case which in my view calls for a total suspension of the sentence ..." The accused was detained till the rising of the court, and the balance of his sentence was suspended for one year. The Medical Council, however, took further disciplinary action against him and his licence to practice was revoked.

Other cases have since appeared before our courts $S v$ McBride ${ }^{51} S v$ Marengo ${ }^{52}$ and $S \vee$ Smorenburg, ${ }^{53}$ all of which found the accused guilty of actively contributing to the death of the respective deceaseds, but all of which gave lenient sentences considering the motive behind acts. Clearly this is a message to the legislature from the judiciary that although the judiciary is forced to enforce the law, community desires, and true sense of

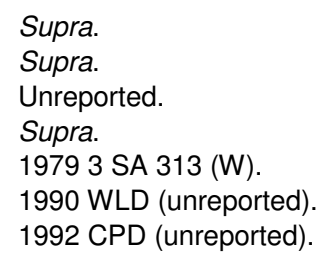


justice as far as blameworthiness prevented them from imposing sentences. What we find then is conviction for the crime of murder or culpable homicide, and then no actual conviction being made because no penalty is suffered. The message is resounding that the boni mores would allow for such "mercy-killing". To avoid the obvious undesired resort to the criminal courts, the legislature should legislate the circumstance.

\section{Switzerland}

In 1918 the Swiss federal government ${ }^{54}$ declared that suicide was not a crime. Clearly the government was ahead of its time, as it further declared that "aiding and abetting suicide can themselves be inspired by altruistic motives." ${ }^{35}$ During that period in time, there were a number of suicides which were spurred on gestures of romance and honour - which were considered as valid motives. ${ }^{56}$ This has been further codified in Article 115 of the Swiss penal code.

A point of note, however, is that assisted suicide is not a crime, and Article 115 does not even require that a physician be involved in the act of ending the life, neither that the patient be terminally ill. ${ }^{57}$ However, euthanasia is subject to criminal sanction. Article 114 refers to "murder upon request of the victim".

The distinction between euthanasia and assisted suicide aside, there has been a vast exodus of people to Switzerland, especially from the United Kingdom, who have done so in order to benefit from Art 115 and thereby end their lives, without fear of penal sanction to those who provide "assistance". ${ }^{58}$

\section{Netherlands}

With an overwhelming majority of the Dutch public (90\% of voters) supporting PAS, the Termination of Life on Request and Assisted suicide Act was passed in 2001. Essentially it was a codification of procedures and norms which had been in practice in the region albeit clandestinely.

In terms of the legislation, PAS was made available to any terminaly ill patient who repeatedly requested it and who met certain criteria. The due-

54 On the first federal penal code.

55 Berne Feuille Federale 1918 IV/I(36) (1918).

56 "Motives around health were not an important concern, and the involvement of a physician was not needed. Euthanasia for terminally ill patients, although intensely discussed in the United States and the United Kingdom in the 1900s, seems not to have been debated in 1918 in Switzerland." Assisted suicide and euthanasia in Switzerland: allowing a role for non-physicians" BMJ http://www.bmj.com/cgi/content/full/326/7383/271.

$57 \quad C f$ with the Oregon legislation where the requirements make such demands in order to avoid criminal (or other) sanction.

58 This, perhaps undesired result, has not been repeated in the Oregon Statute, which makes one of the requirements to qualify for Assisted Suicide, that the patient be a resident of the State of Oregon (proof of which is required). 
care requirements mentioned in Criminal Code Article 293 (which exempt liability for murder), paragraph two, stipulate that the physician:

- must be convinced that the patient has made a voluntary and wellconsidered request to die;

- must be convinced that the patient is facing an interminable and unendurable suffering;

- has informed the patient about his situation and his prospects;

- together with the patient, must be convinced that there is no other reasonable solution;

- has consulted at least one other independent doctor of the patient;

- has seen and given his written assessment of the due care requirements as referred to in points 1 to 4 ; and

- has helped the patient to die with due medical care.

A regional review committee then assesses whether a case of termination of life on request or assisted suicide complies with the due-care criteria. If the committee is of the opinion that the physician has practised due care, the case is closed. But if that is not so, the case is brought to the attention of the Public Prosecutor. The Public Prosecutor does, of course, have the power to launch his own investigation if he suspects that a criminal act may have been committed.

However, the case of Chabot $^{59}$ heard in the Netherlands Supreme Court is significant too. Here the suffering of the 50-year old woman was psychological. She had a long history of suffering depression and when both her sons died she decided to commit suicide. She was referred to $\mathrm{Dr}$ Chabot by the Dutch Federation for Voluntary Euthanasia after she had contacted them for assistance. Dr Chabot diagnosed her as suffering from severe and intractable mental anguish and was of the opinion that her case satisfied the prescribed guidelines. He consulted a number of colleagues, but none of them examined her. He assisted her to commit suicide by prescribing a lethal dose of drugs and reported the case to the coroner. He was prosecuted under Art 294 of the Dutch Penal Code. The Supreme Court held that there was no reason in principle why the defence of necessity could not apply where a patient's suffering is purely psychological. However, for the defence to apply, the patient must have been examined by an independent medical expert. Since this had not happened in this case, Dr Chabot was found guilty of an offence under Article 294.

Here the court expressed acceptance of euthanasia for persons not suffering from any physical disease. (In spite of this finding, the doctor was pronounced guilty because he had not consulted a colleague in regard to examining the patient.)

$59 \quad 21$ June 1994 Nederlandse Jurisprudensie 656. 


\section{CAN CONSENT ACT AS A DEFENCE?}

\section{Requirements for consent to be valid}

- Consent must be recognized by law as a possible defence.

- It must be real consent.

- It must be given by a person capable in law of consenting.

For consent to act as a defence, it must be part of the definitional elements of the crime (as in rape) and in such circumstances, the consent of the victim will cleanse the act of its criminal nature as a result of the application of the principle volenti non fit injuria.

The rule follows through such that an individual is permitted to consent to the risk of serious bodily harm, or even death, provided that the cause of running that risk is inflicted during the course of normal therapeutic medical operations or treatment. But this will not always be a defence as the common law does not allow consent of the victim to act as a defence where the victim consents to being killed, ${ }^{60}$ and the person administering the lethal dose would be found guilty of murder, despite such "consent". 61

The reality, however, is that societal tolerances and attitude to death, dying and voluntary euthanasia are fluid and in fact not static, and there appears to be an increasing trend towards allowing and aiding individuals to die with dignity.

Although the relevant principle is volenti non fit injuria, we see from the legislation, and judicial precedent, that is not always the case. Although it is accepted that people are able to make decisions for themselves and live with those consequences, the attitude that the authorities prevent and punish people for making certain types of decisions, still prevail. Hence the need to legislate out of liability in regard to certain "victimless crimes". ${ }^{2}$

When it comes to crimes, the general rule is that consent of the victim will not suffice as a defence, and this is so because consent will only be successful as a defence where "it is in the interests of public policy that the act of the offender should be rendered not unlawful by the consent of the victim.",63

However, it is evident that public policy, tolerance and acceptance certainly is gauged on a sliding scale. The author is not suggesting a degeneration of morality, merely that perceptions and tolerances are by no means static, and in fact, rather are fluid, to serve the community (as communal needs and values change) in which they are meant to operate.

\footnotetext{
Ex Parte Die Minister van Justisie: In re S v Grotjohn supra 363.

$S v$ Hartman supra 534.

LAWSA Vol 6 par 105.

Burchell Principles of Criminal Law 3ed (2005) 324.
} 
That being said, public policy accepts consent to bodily harm (or the risk of injury) but will not accept consent to death. Thus one cannot raise as a defence to having caused the death of a victim, that the victim consented. This has been firmly established in the SA common law. One merely needs to look at $R v$ Peverett, ${ }^{64} S v$ Robinson, ${ }^{65}$ Ex Parte Minister van Justisie: In re Grotjohn, ${ }^{66} S v$ Hartmann, ${ }^{67} S v$ Belloc ${ }^{68}$ and $S v$ Hibbert. ${ }^{69}$

In Baxter $^{70}$ the Supreme Court looked at physician liability and whether consent would act as a defence in the PAS situation. It looked at the homicide statute and held that consent would be a defence by first asking whether consent as a defence applies at all re PAS and then whether patient consent was rendered ineffective by subsections $45-2-211(2)(d)^{71}$ of the MCA because permitting the conduct or the resulting harm was "against public policy".

The court confined its decision to the question of public policy, and found that "physician aid in dying ... does not fall within the scope of what this Court has thus far identified as 'against public policy"'. It made comparison to the Court's earlier decision in Mackrill, ${ }^{72}$ where the court applied the "against public policy" exception to situations in which violent, public altercations breach public peace and endanger others in the vicinity.

"The ... case(s) addresses assaults in which the defendant alone performs a direct and violant act that causes harm. The bar brawler, prison fighter, BB gun-shooter, and domestic violence aggressor all committed violent acts that directly caused harm and breached the public peace. It is clear from these cases that courts deem consent ineffective where defendants directly commit blatanly aggressive, peace-breaching acts against another party.

In contrast, a physician who aids a terminally ill patient in dying is not directly involved in the final decision or the final act. He or she only provides a means by which a terminally ill patient himself can give effect to his life-ending decision, or not, as the case may be. Each stage of the physician-patient interaction is private, civil, and compassionate. The physician and terminally ill patient work together to create a means by which the patient can be in control of his own mortality. The patient's subsequent private decision whether to take the medicine does not breach public peace or endanger others."

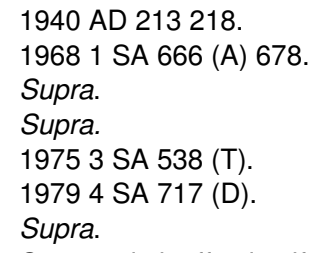

Consent is ineffective if: "(a) if it is given by a person who is legally incompetent to authorize the conduct charged to constitute the offence; (b) it is given by a person who by reason of youth, mental disease or defect, or intoxication is unable to make a reasonable judgment as to the nature or harmfulness of the conduct charged to constitute the offence; (c) it is induced by force, duress, or deception; or (d) it is against public policy to permit the conduct or the resulting harm, even though consented to."

72 State v Mackrill 2008 MT 297, 345 Mont. 469, 191 P.3d 451.

73 Baxter supra par 23-24. 


\section{RECOMMENDATIONS - THE POSITION OF THE PHYSICIAN - LIABILITY}

Under South African law both suicide and attempted suicide are legal. ${ }^{74}$ However, PAS and euthanasia are not. Central to the arguments around continued criminalization is whether or not the assistance rendered in ending one's life was a novus actus interviniens. As pointed out above, our courts have unequivocally held that such assistance is a criminal offence - murder, attempted murder or culpable homicide ${ }^{75}$. This means that only the physician who has prescribed the lethal medication can be prosecuted. However, of significance is the sentence handed down to the accused in each of the cases.

The other leg of the debate considers various human rights in the Bill of Rights in the Constitution. ${ }^{76}$ The right to personal liberty (autonomy), the right to life and the right to emergency medical treatment, are at loggerheads. It is evident from the case law that the right to life is paramount (part of the reason why PAS is illegal), and yet, in Soobramoney ${ }^{77}$ the court ruled effectively to allow a person to die by denying him treatment - the premise being that emergency treatment would be made available to a patient where there was a reasonable hope that he might recover. Thus doctors were neither expected nor obligated to keep patients on treatment where their professional opinion was that the situation was hopeless. This is certainly strong argument in favour of the legalization of PAS.

In 1998 the South African Law Commission in its Report on Euthanasia and the Artificial Preservation of Life $^{78}$ considered the issue and recommended the following as options regarding active voluntary euthanasia:

"Option 1: Confirmation of the present legal position:

The arguments in favour of legalizing euthanasia are not sufficient reason to weaken society's prohibition of intentional killing since it is considered to be the cornerstone of the law and of all social relationships. Whilst acknowledging that there may be individual cases in which euthanasia may seem to be appropriate, these cannot establish the foundation of a general pro-euthanasia policy. It would furthermore be impossible to establish sufficient safeguards to prevent abuse."

74 Hunt South African Criminal Law and Procedure, Volume II: Common Law Crimes (1972); and this is also the case in Montana "We start with the proposition that suicide is not a crime under Montana law. In the aid in dying situation, the only person who might conceivably be prosecuted for criminal behaviour is the physician who prescribes a lethal dose of medication." - Supreme Court of Montana Baxter v Montana 2009 MT 44911.

75 S v Peveret 1940 AD 213; S v Nbakwa supra; S v Gordon supra; and Ex Parte Minister of Justice: S v Grotjohn 19702 SA 355 (A).

76 Act 108 of 1996

77 Soobramoney $v$ The Minister of Health (KZN) 19981 SA 765 (CC).

78 South African Law Commission Report, Project 86 "Euthanasia and the Artificial Preservation of Life" (November 1998). 
It is respectfully submitted that it is not desirable for the status quo to remain. A clear message has been sent from the judiciary to the legislature that where the patient is competent, and able to make his own decisions, when a physician takes steps necessary to give life to such directive, the court will take those factors into consideration, and although it may make a finding of guilt in terms of the law, the sentence pronounced certainly shows a tolerance and acceptance of the volenti principle.

"Option 2: Decision-making by the medical practitioner:

The practice of active euthanasia is regulated through legislation in terms of which a medical practitioner may give effect to the request of a terminally ill, but mentally competent patient to make an end to the patient's unbearable suffering by administering or providing a lethal agent to the patient. The medical practitioner has to adhere to strict safeguards in order to prevent abuse."

"Option 3: Decision-making by a panel or committee:

The practice of active euthanasia is regulated through legislation in terms of which a multi-disciplinary panel or committee is instituted to consider requests for euthanasia according to set criteria."

It is submitted that the solution against potential abuse lies in the above two postulated options. If the cue is taken from the Oregon Statute (supra), the noble objectives of alleviating suffering and allowing a person to die with dignity can be met. As a society plagued with the HIV/AIDs virus, cancer and other debilitating, terminal illnesses, there arises a need for such a measure. It is submitted that it has been 12 years since the law commission report and its draft bill were presented to the community, that the debate should be reopened in the face of the health status of the community. It is far better that assisted suicides be conducted in a manner that can be regulated and under the trained eye and skill of a physician, rather than the patient being left to resort to more drastic, painful and inhumane ways of ending his own suffering.

In light of the strides made in the Baxter ${ }^{79}$ decision, it is submitted that a fourth option now looks viable: Use of the Constitution ${ }^{80}$ and the rights to equality (section 9), human dignity (section 10), and privacy (section 14) guaranteed therein to secure ones "right" to die with dignity and assistance.

Prof. Labuschagne argued that voluntary euthanasia should be legalized. His submission to the South African Law Reform Commission was that:

"legislation that would legalize the cessation of treatment as well as active euthanasia in circumstances where:

(a) The patient must be suffering from a terminal illness;

(b) the suffering must be subjectively unbearable;

(c) the patient must consent to the cessation of treatment or administering of euthanasia;

$\begin{array}{ll}79 & \text { Supra. } \\ & \text { Supra. }\end{array}$ 
(d) the above-mentioned condition and facts must be certified by at least two medical practitioners.

According to Labuschagne the concept of informed consent is based on the principles of human individuality, dignity and autonomy and forms one of the fundamental tenets of euthanasia.

\section{IS THE RIGHT TO DIE CONSTITUTIONALLY GUARANTEED?}

This question has yet to be unanswered by the courts. However, there appears to be some indication by way of obiter remark in $S v$ Makwanyane. ${ }^{83}$ The court asked, but failed to give an answer:

"Does the 'right to life', within the meaning of s9, preclude the practitioner of scientific medicine from withdrawing the modern mechanisms which mechanically and artificially enable physical breathing in a terminal patient to continue, long beyond the point when the 'brain is dead' and beyond the point when a human being ceases to be 'human' although some unfocused claim to qualify as a 'being' is still retained? If not, can such a practitioner go beyond the point of passive withdrawal into the area of active intervention? When? Under what circumstances?"

This remark, and the sentiment expressed in Soobramoney, ${ }^{84}$ are indicative of the fact that the right to choose to die with assistance could be constitutional. Clearly, tolerances from the bench can be seen in the sentences meted out thus far for such assistance, and it is submitted that the bill as drafted by the SALRC should be revisited. International trends show that abuses do not occur as a result of placing checks and balances and strict criteria for qualification of the PAS procedure.

\section{CONCLUSION}

It is submitted that "[t]here remains room for vigorous debate about the outcome of particular cases that are not necessarily resolved by the opinions announced ... How such cases may be decided will depend on their specific facts. ${ }^{85}$ In the author's judgement, however, it is clear that the so-called "unqualified interest in the preservation of human life" in light of the Constitution as well as the entrenched guarantees held there in.

\footnotetext{
Par 4.114 SALC Report on Euthanasia above.

Ibid.

19956 BCLR 665 (CC) par 268.

Supra.

85 Survey of Books Relating to the Law "Review: Euthanasia in America: Past, Present, and Future: A Review of a 'Merciful End' and 'Forced Exit'” May 2004 102(6) Michigan Law Review 12451259.

86 Cruzan, 497 U.S. 282, Glucksberg, ante 24, is not itself sufficient to outweigh the interest in liberty that may justify the only possible means of preserving a dying patient's dignity and alleviating her intolerable suffering" (506).
} 
Perhaps the words of O'Regan $\mathrm{J}$ in Makwanyane ${ }^{87}$ should be seen as platform to advocate for the legislature to re-open the debate: "The right to life, thus understood, incorporates the right to dignity. So the rights to human dignity and life are entwined. The right to life is more than existence $\square$ it is the right to be treated as a human being with dignity: without dignity, human life is substantially diminished".

In a community that values autonymity and has placed much emphasis on patient freedom of choice - where a patient can refuse further medical treatment - it seems that the logical next step would be to extend recognition of such autonomy to the request for PAS. As stated by O'Regan $\mathrm{J},{ }^{88}$ human beings should, as a recognition of the rights to dignity and autonomy, be allowed to choose the manner and time of their dying.

Egan ${ }^{89}$ states that "Where patients are able to do so, they have the right to decide for themselves whether to undergo or to refuse treatment. Increasingly too, where they are physically unable to make such decisions for themselves, other persons who know them are able to stand in for them and make proxy decisions. Although as yet they have no legal standing, 'living wills' are also used as a source of direction for doctors as to their desire for certain forms of medical treatment." So why not extend this reasoning to include PAS?

He goes further to argue that "since physicians should (within reason) respect he wishes of morally autonomous (that is, adult) patients, the request for PAS should be honoured if their condition is hopeless and they experience great suffering, including pain that cannot reasonably be alleviated".

Extending this to the statement by $\mathrm{O}^{\prime}$ Regan $\mathrm{J}^{90}$ regarding dignity and life, PAS appears to, by an acceptable and merciful alternative, to offer a terminally ill human being a humane choice/option to enduring extreme suffering until the end.

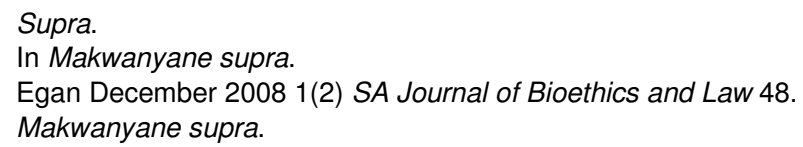

